\title{
Research of Effective Microorganisms on Dairy Sewage Sludge Stabilization
}

\author{
Dariusz Boruszko' \\ 1 Faculty of Civil and Environmental Engineering, Bialystok University of Technology, ul. Wiejska 45A, 15-351 \\ Bialystok, Poland, e-mail: d.boruszko@pb.edu.pl
}

\begin{abstract}
The present paper was aimed at determining the influence of particular methods and biological processes, including the application of Effective Microorganisms, on the change in characteristics of the treated dairy sewage sludge, especially when discussing the changes in the content of nutrients and macroelements. The purpose of the conducted research was to specify the possibility of using natural biological methods of dairy sewage sludge treatment and adapting it to environmental, especially farming use. Diagnostic research on the content of sewage sludge from dairy wastewater treatment plants in the north-eastern region of Poland has been conducted since the 1990s. On the basis of the results and the assessment of the possibility of agricultural utilization of dairy sewage sludge, the objectives for research on sludge treatment were established. The research facilities were located on the premises of Municipal Wastewater Treatment Plant in Zambrów. The choice of location for the research facilities was guided by the possibility of supplying the same sludge from dairy wastewater treatment. The excess sludge from biological dairy sewage treatment, which was aerobically stabilized in separate chambers, was used in the research. In all of the facilities where sludge was treated with biological methods, Effective Microorganisms (EM) were also used for comparison. In the years 2010-2013, the research was conducted in the research facilities (own project) constructed and launched in 2010, which were planted with phragmites and common osier. In the years 2010-2012, the research was conducted in the research facilities (own project) constructed and launched in 2010, i.e. vermiculture patches. The conducted research was comprehensive and the obtained experiment results point to the necessity of continuation and further development of research concerning the content transformation in dairy sewage sludge during its biological treatment. Establishing the role of microorganisms present in the EM formula on the processes and transformations occurring in biologically treated sewage seems to be of exceptional importance. The innovativeness of the research lay mainly in a very comprehensive range of natural biological methods of treatment applied for the same sewage sludge coming from dairy wastewater treatment plants. The conducted research points to the influence of the EM formula on vital changes in the content of macroelements in the biologically treated dairy sewage sludge. The most important impact (from the point of view of the number of parameters and the change in size as a result of applying EM formula) was observed in reference to the vermicomposting process with the use of earthworms and long-term stabilization in reed beds. The statistical assessment methods applied to the obtained results of own research (Wilcoxon and Spearman tests, Spearman's rank correlation coefficient) point to a significant influence of the EM formula on different "behavior" of many analyzed characteristics of the treated sludge.
\end{abstract}

Keywords: dairy sewage sludge, vermiculture, Effective Microorganisms, stabilization in reed beds, energy-crop willow

\section{INTRODUCTION}

In the research conducted so far on agricultural application of dairy sewage sludge, there have been no attempts at using microbiological inoculations containing Effective Microorganisms for faster disintegration of organic matter introduced into the soil. The inventor of effective Microorganisms technology is Professor Teruo Higa from the Agricultural Academy in the Ryukyus, Okinawa, Japan. In Poland, a preparation containing Effective Microorganisms has been distributed for nearly 20 years under the name EM and there are few detailed scientific studies on this subject. Both domestic and foreign research connected with production 
of compost, vermicompost, recultivation substances and natural fertilizers to a great extent refer to the municipal sludge with the content and characteristics different than the dairy sludge. The author believes that it is crucial to determine the usefulness of various ways of dairy sewage sludge treatment through low-cost methods and with the application of Effective Microorganisms.

The scientific purpose of this project and the subject of the conducted research were determining the influence of particular low-cost methods and processes, including the use of Effective Microorganisms, on the change of characteristics and parameters of the processed dairy sewage sludge.

It is crucial to introduce and establish the usefulness of simple and cheap stabilization and composting methods. These methods do not require using chemical additives, are effective in the sanitization process, generate organic substances of very high quality, can be applied everywhere and are not harmful to the environment. The possibility of applying natural low-cost stabilization and dewatering methods with the use of energy-crop willow and common reed was also examined.

Effective Microorganisms technology is based on inoculation with the microorganisms existing only in the natural environment, appropriately selected and meeting strict criteria concerning the lack of hazard for people, animals and plants. The beneficial effect of Effective Microorganisms was shown, which consisted in the change of surrounding microflora towards its regeneration. It causes maintaining the $\mathrm{N}: \mathrm{P}: \mathrm{K}$ and $\mathrm{C}: \mathrm{N}$ ratios at an optimal level in the surrounding environment. The formula was also proven to have an effect of eliminating the decay processes in the soil by accelerating the transformations of organic matter [Higa 1994, 1996].

Dairy sewage is characterized by much higher values of pollution indicators in comparison with municipal sewage [Anielak 2008, Boruszko and Butarewicz 2015, IPPC Reference Document 2006].

The sewage sludge from dairy wastewater treatment may be therefore applied for environmental purposes, for fertilization and recultivation in farming. Much research presented in the literature connected with the problem of sewage sludge management point out that the dairy sewage sludge is characterized by a low content of heavy metals in comparison with the municipal sewage sludge in Poland and around the world [Boruszko 2017, Dąbrowski 2006, 2008, Rosik Dulewska et al. 2009].
While analyzing the literature data on the content of selected microelements (calcium, magnesium, nitrogen and phosphorous, many authors show higher values in dairy than in municipal sewage sludge [Boruszko 2011, Dusza et al. 2009, Lopez-Mosquera et al. 2000].

\section{METHODS}

\section{Characteristics of the research subject}

The research installations for low-cost sewage sludge treatment, such as common reed beds, energy-crop willow beds and vermicompost beds designed and created by the author, constituted the subject of the research.

The excess sewage sludge from biological dairy wastewater treatment which was aerobically stabilized in separate chambers, sampled from the wastewater treatment plant SM Mlekovita in Wysokie Mazowieckie was the research substrate. The substrate, depending on the research installation, was initially thickened or dewatered.

The vermicompost beds were supplied with the same dairy sewage sludge, but with approximately $80 \%$ single-time hydration in the amount of $1.5 \mathrm{~m}^{3}$ of hydrated sludge per one bed of $4 \mathrm{~m}^{2}$ area. Before supplying the bed with sewage sludge, it was embanked with a so-called stock nursery containing red Californian earth worms from the wastewater treatment plant in Zambrów. One section of the research installation containing vermiculture was supplied with the EM formula once per month during the vegetation period, with 3 liters per section.

The reed beds were planted with 5 one-yearold reed seedlings from the wastewater treatment plant in Zabrów per $\mathrm{m}^{2}$, while the beds with energy-crop willow - with 4 one-year-old seedlings of Salix viminalis from a private tree nursery per $\mathrm{m}^{2}$. Supplying the installation with dairy sewage sludge began in May 2010 with $0.5 \mathrm{~kg}$ of dry mass per $\mathrm{m}^{2}$ of a section, gradually increasing the amount to $2.0 \mathrm{~kg} \mathrm{dm} / \mathrm{m}^{2}$ of a section. The frequency was increased from one per 3-4 weeks to one per 1-2 weeks (the supplied sewage sludge was initially thickened with approximately $95 \%$ hydration). In two sections of the research installation, i.e. one containing willow and one - reed, 1 liter of the EM formula was applied per section once a month during the vegetation period. 
Effective Microorganisms were also applied in all methods for comparison. The EM-BIO formula produced by Greenland - EM Technology was applied. The formula created by this company has authenticity and originality certificates confirmed by dr Teruo Higa, the inventor of Effective Microorganisms, professor emeritus at University of the Ryukyus, Director of International Institute for EM Research Technology at Meio University.

The basic element in the low-cost treatment processes was the sewage sludge from the SM Mlekovita dairy wastewater treatment plant in Wysokie Mazowieckie. The same dairy sewage sludge was used in all research installations for comparative purposes.

\section{Vermicomposting research methods}

The applied dairy sewage sludge vermicomposting process was conducted for two vegetation periods.

The research frequency was adjusted to the characteristics of the technological process and the features of the controlled parameters. The established methods assumed 5 test series of vermicompost mixture samples from each section:

- the samples collected from the dairy sewage sludge applied in the vermicomposting process - the start of vermicomposting (the beginning of earthworms biological activity season (spring - May) in the first year - Phase 0)

- the samples collected after 5 months of vermicomposting process - the end of earthworms biological activity season (autumn - October) in the first year - Phase I;

- the samples collected after 12 months (year 1) of vermicomposting - the beginning of earthworms biological activity season (spring May) in the second year - Phase II;

- the samples collected after 17 months of vermicomposting process - the end of earthworms biological activity season (autumn October) in the second year - Phase III (end of proper vermicomposting);

- the samples collected after 24 months - representative for the end of vermicompost maturing phase (mature vermicompost - spring May) - Phase IV.

The vermicomposting period in the sections was 2 years ( 2 vermiculture vegetation seasons). After that period, each of the sections was deconstructed and their content was deposited on an open-air pile in order to finish the maturing process (6 months).

\section{Research methods - reed and energy-crop willow beds}

The applied long-term stabilization process of dairy sewage sludge in beds with reed and energy-crop willow was conducted for a period of four years (four vegetation seasons).

The research frequency was adjusted to the characteristics of the technological process and the features of the controlled parameters. The established methods assumed 7 test series of treated sewage sludge samples from each section:

- the samples collected after 5 months of stabilization process - the end of vegetation season in the first year - Phase I;

- the samples collected after 12 months (1 year) of stabilization - the beginning of vegetation season in the second year - Phase II;

- the samples collected after 17 months of stabilization process - the end of vegetation season in the second year - Phase III;

- the samples collected after 24 months of stabilization - the beginning of vegetation season in the third year - Phase IV;

- the samples collected after 29 months of stabilization process - the end of vegetation season in the third year - Phase V;

- the samples collected after 36 months of stabilization process - the beginning of vegetation season in the fourth year - Phase VI;

- the samples collected after 41 months of stabilization process - the end of vegetation season in the fourth year - Phase VII.

The samples were collected with the help of a probe intended for this specific purpose. The research samples were always collected from the same lowest $10 \mathrm{~cm}$ layer of sludge in a vertical profile.

During the four-year sewage sludge stabilization period in reed and energy-crop willow beds, the content of sewage sludge that the beds were supplied with was monitored using averaged samples four times a year.

\section{Analytical research methods}

The scope of sewage sludge research during its treatment with biological methods included the following physicochemical parameters: 
- the $\mathrm{pH}$ parameter.

The parameter was established according to PN-EN 12176:2004 standard.

- Dry mass parameter.

The parameter was established according to PN-EN12880:2004 standard.

- Organic substance parameter.

The parameter was established according to PN- EN 12879: 2004 standard.

- Total nitrogen parameter.

The parameter was established according to PN- EN 13342: 2002 standard.

- Total phosphorous parameter.

The parameter was established according to PB $262^{\text {nd }}$ Edition, 06.04.2009, PB $263^{\text {rd }}$ Issue, 20.01.2011, PB $264^{\text {th }}$ Issue, 05.01.2012 standard.

- Total potassium, calcium and magnesium parameter.

The parameter was established according to PB $272^{\text {nd }}$ Edition, 06.04.2009, PB $273^{\text {rd }}$ Issue, 20.01.2011 standard.

- Total sulfur content parameter.

The parameter was established according to PB $242^{\text {nd }}$ Edition, 08.10.2008, PB $243^{\text {rd }}$ Issue, 14.01.2011, PB $274^{\text {th }}$ Issue, 05.01.2012 standard.

\section{RESULTS AND DISCUSION}

The changes in the basic characteristics and content of macroelements, observed as a result of the research, were the consequence of microbiological and biochemical transformations occurring during stabilization and dewatering in the beds with energy-crop willow and reeds, as well as in the vermicomposting process.

The Figures 1, 2 and 3 present changes over time in the analyzed physical characteristics and macroelements content in the sewage sludge in particular phases of vermicomposting and longterm stabilization.

In reference to the sewage sludge characteristics and its examined content of macroelements, the greatest influence of EMs was observed in the vermicomposting process. The changes result in the content of the analyzed macroelements in sewage sludge, in particular the phases of it being processed by earthworms, in reference to the EM inoculation, show very similar values, but several differences were also observed. For mature vermicompost in which production EM was used, higher contents of phosphorous and nitrogen were observed, while the contents of potassium, calcium, magnesium and sulfur was lower than in the mature vermicompost in which production EM was not used. Adding EM to the vermicomposting process also influenced the increase of the phosphorous content in sewage sludge and higher content of dry mass which points to better mineralization. The organic substance content in the mature vermicompost with EM was over 5\% higher than in the vermicompost without EM. An even greater difference was observed in dry mass: mature vermicompost with EM had over 8\% more dry mass than vermicompost without EM. Adding EM to the beds with common reed and willow during dairy sewage sludge long-term stabilization and dewatering processes caused an increase in the sulfur and magnesium content, while at the same time it decreased the calcium content. A higher content of organic substance was also observed in reed and energy-crop willow beds.

\section{Interdependencies for characteristics examined in the experiments - statistical analysis}

The consequence of biochemical processes in various methods applied for treating the sewage sludge from dairy wastewater treatment involved the changes in the physicochemical characteristics of the sewage sludge. In order to examine the interdependencies for the examined sewage sludge characteristics, various description and statistical analysis methods were applied: Wilcoxon signedrank test and Spearman rank correlation.

\section{Wilcoxon signed-rank test}

In order to examine whether a statistically significant change occurred, Wilcoxon signedrank test was applied for particular matched pairs. The same characteristics of sewage sludge with and without EM in all of the treatment processes were chosen as matched pairs and subjected to the test. Table 1 presents the results of the Wilcoxon test statistical calculations for the chosen characteristics and the macroelements content in the dairy sewage sludge processed in the research installations.

The assumed zero hypothesis stated that "parameters compared in pairs (sewage sludge with and without EM) for the most part of the treatment process do not differ, i.e. there are 
1.1

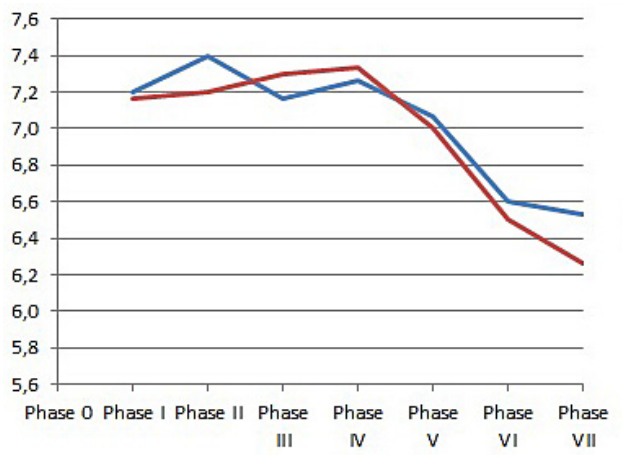

1.3

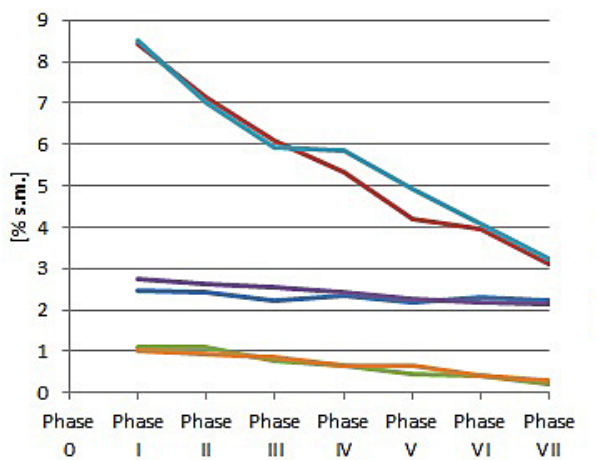

1.2

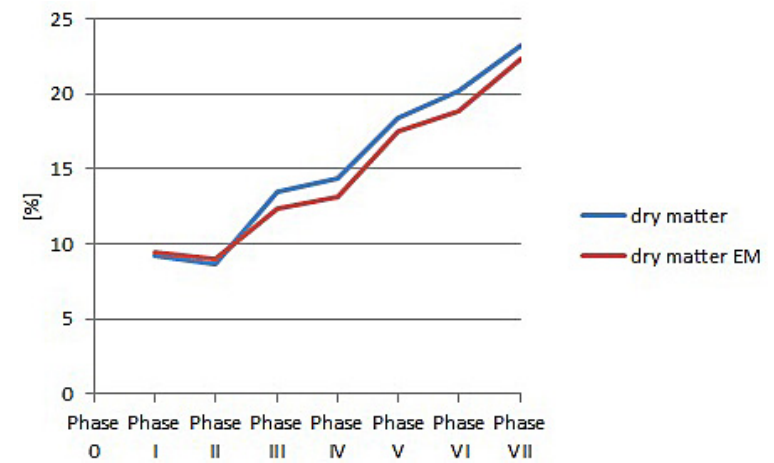

1.4

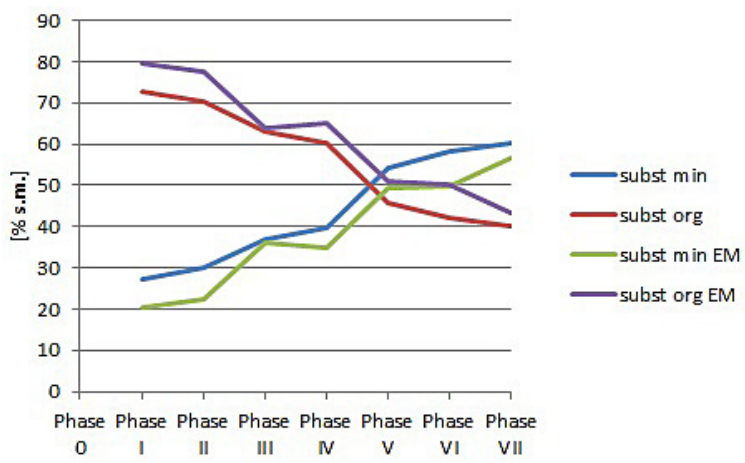

1.5

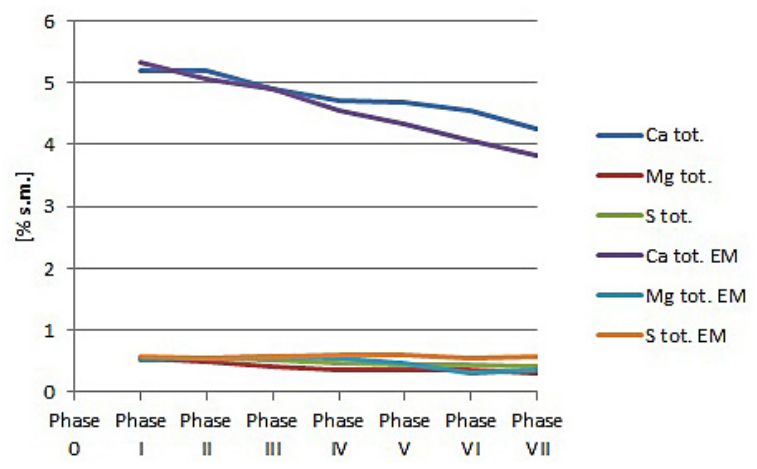

Figure 1. Changes in selected characteristics and macroelements content and percentage changes in the share of macroelements in the dairy sewage sludge treated in the research installation with energy-crop willow

no significant differences between the matched pairs". Reaching probability with BenjaminiHochberg correction greater than $p>0.05(p-$ test value with multiple testing corrections) was the basis for rejecting the zero hypothesis. An alternative test hypothesis was assumed that "significant differences occur between the matched pairs". The zero hypothesis is rejected in favor of the alternative hypothesis when $p<0.05$. For statistically significant tests, post-hoc was determined. The numeral values of the test statistics show which measurements (either for sewage sludge with or without EM) are significantly larger or smaller.
A general analysis of Wilcoxon signed-rank test points to various behaviors of particular sewage sludge characteristics during long-term processing in reference to the influence of EM addition.

In reference to the sewage sludge characteristics and its content of the examined macroelements (tab. 1), the greatest EM influence was observed in the vermicomposting process. The achieved low $p$ value (from 0.0065 to 0.0084 ) and high value of test statistics (from 66 to 78 ) show that EM addition caused a significant decrease of potassium, calcium, magnesium and sulfur in sewage sludge during vermicomposting process and in mature vermicompost. 


\section{1}

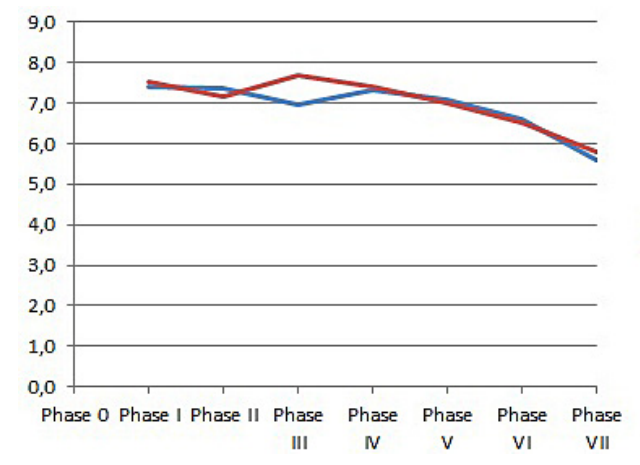

\section{3}

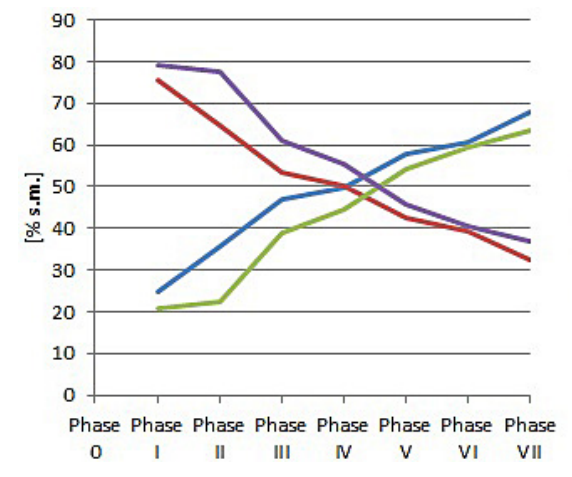

2.2

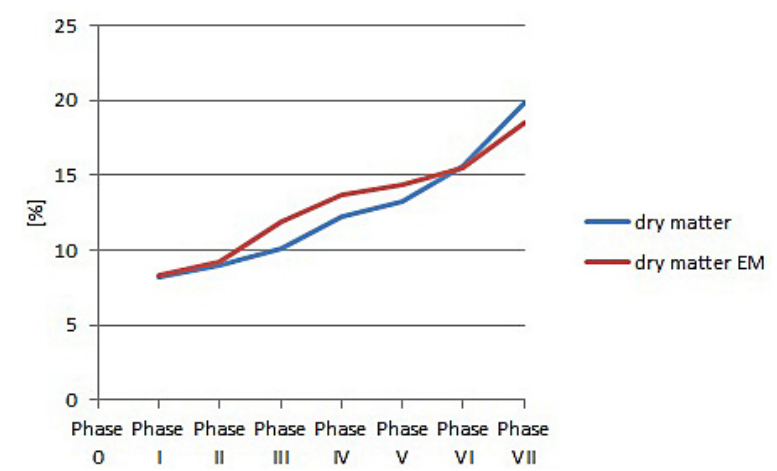

2.4

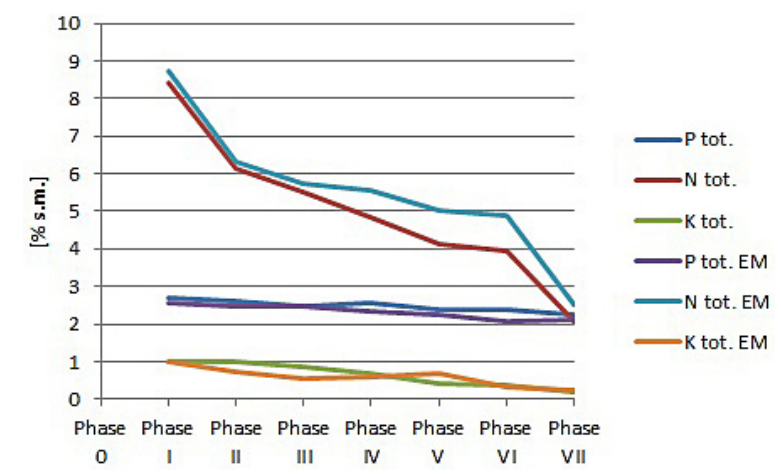

2.5

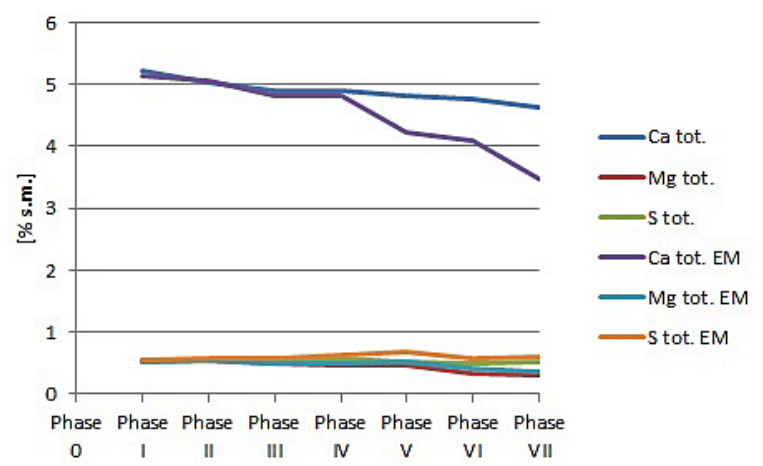

Figure 2. Changes in selected characteristics and macroelements content and percentage changes in the share of macroelements share in the dairy sewage sludge treated in the research installation with common reed

A similar effect was observed for $\mathrm{pH}$. However, adding EM to the vermicomposting process influenced the increase of phosphorous content in sewage sludge, its cumulation and higher dry mass content indicating its better mineralization. The slightest influence of EM addition on the analyzed characteristics and macroelements content was observed for composting and solar sewage sludge drying; significant differences were recorded only for three parameters. In the case of composting, the EM addition caused a general increase of calcium $(\mathrm{p}=0.017$ and $\mathrm{Stat}=7.5)$ and a significant decrease of the potassium content $(\mathrm{p}=0.038$ and Stat $=91)$ during sewage sludge processing. The EM addition in the long-term stabilization had a significant influence on most of the tested parameters. In both cases, it caused sulfur (p from 0.0001 to 0.001 and Stat from 5 to 11 ) and magnesium ( $p$ from 0.005 to 0.0112 and Stat from 22 to 23) to increase, while at the same time caused calcium ( $\mathrm{p}$ from 0.0014 to 0.005 and Stat from 204 to 213.5) and mineral substances (p from 0.0002 to 0.0006 and Stat from 225 to 231) to decrease. A simultaneously higher content of organic substances was observed in the sewage sludge in reed and energy-crop willow beds. 
3.1

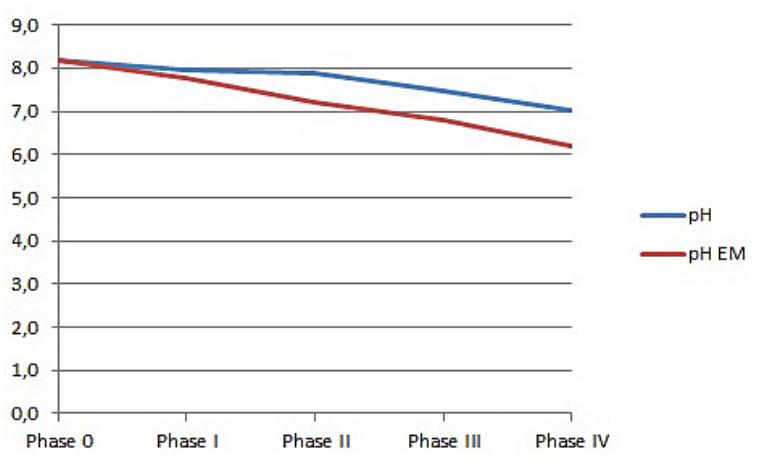

3.3

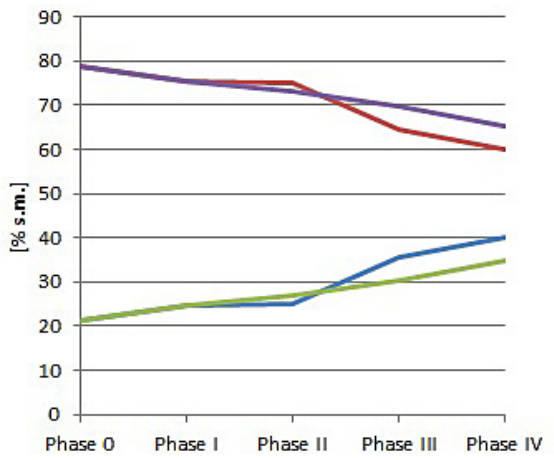

3.2

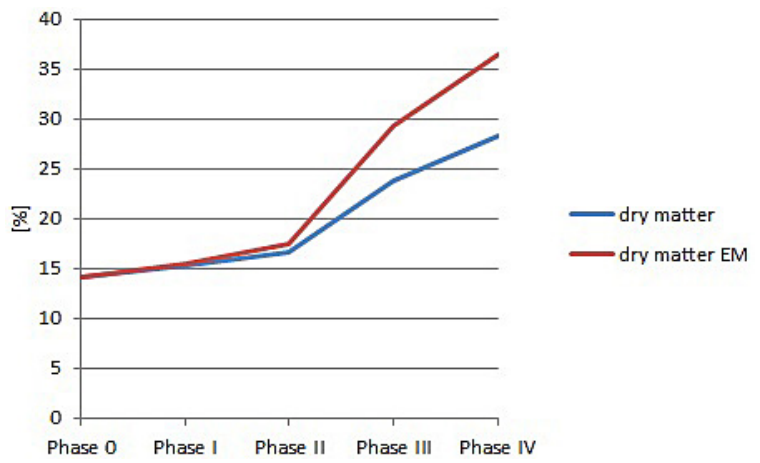

3.4

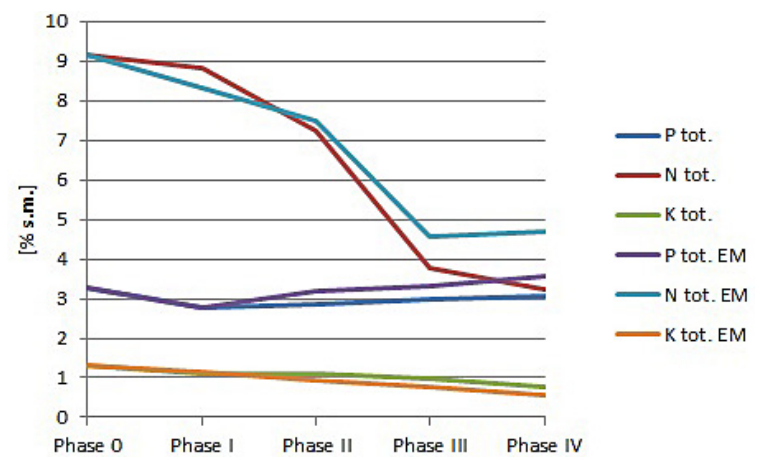

3.5

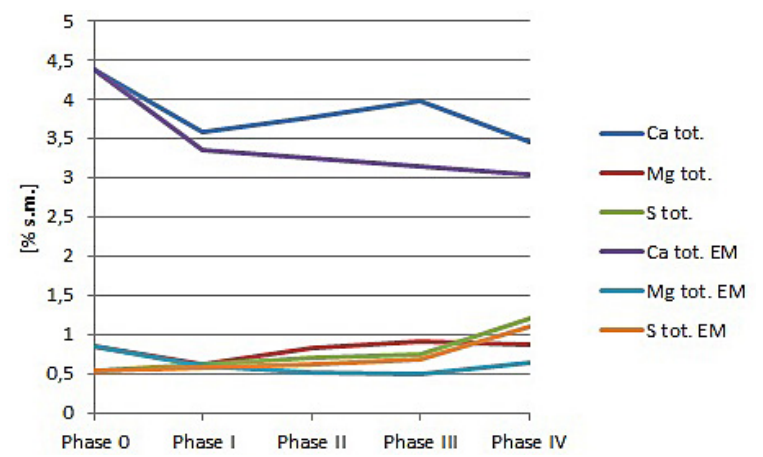

Figure 3. Changes in selected characteristics and macroelements content and percentage changes in the share of macroelements in the dairy sewage sludge treated in the research installation with vermicompost

\section{Spearman correlation coefficient significance (rank) test}

Spearman correlation coefficient test was applied in order to examine the dependencies between quantity parameters and to describe the correlation intensity. Table 2 presents results of the statistical calculations for Spearman correlation rank for all testing series and parameters within the conducted experiment.

The marked correlation coefficients are significant when $p<0.05000$. Spearman rank correlation coefficient $S$ takes values from $[-1 ; 1]$ range. Equal ranks of the tested variables values prove the existence of a positive correlation between them $(\mathrm{X}=\mathrm{Y}=1)$, that is $\mathrm{Y}$ increases whenever $\mathrm{X}$ does and vice versa. Opposite numeration suggests the existence of a negative correlation. A positive coefficient mark means that there is positive interdependency, while a negative mark indicates that there is negative interdependency. The closer a coefficient is to unity, the more intensive is the correlation.

The assumed zero hypothesis stated that "parameters compared in pairs (sewage sludge with and without EM) show a lack of behavior correlation in time". Reaching probability with Benjamini-Hochberg correction greater than $p>0.05$ 
Table 1. Wilcoxon test results for selected characteristics and macroelements content in the dairy sewage sludge treated in the research installation

\begin{tabular}{|c|c|c|c|c|c|c|c|c|c|c|}
\hline & Reaction & $\begin{array}{c}\text { Mineral } \\
\text { substances }\end{array}$ & $\begin{array}{c}\text { Organic } \\
\text { substances }\end{array}$ & $\begin{array}{c}\text { Dry } \\
\text { mass }\end{array}$ & $\begin{array}{c}\text { Total } \\
\text { phosphorous }\end{array}$ & $\begin{array}{c}\text { Total } \\
\text { nitrogen }\end{array}$ & $\begin{array}{c}\text { Total } \\
\text { potassium }\end{array}$ & $\begin{array}{c}\text { Total } \\
\text { calcium }\end{array}$ & $\begin{array}{c}\text { Total } \\
\text { magnesium }\end{array}$ & $\begin{array}{l}\text { Total } \\
\text { sulfur }\end{array}$ \\
\hline \multicolumn{11}{|c|}{ Willow } \\
\hline$p$ & 0.2052 & 0.0006 & 0.0006 & 0.0031 & 0.0154 & 0.0618 & 0.3506 & 0.005 & 0.005 & 0.001 \\
\hline Stat. & 95.5 & 225 & 6 & 210 & 40.5 & 57 & 85 & 204 & 22 & 11 \\
\hline Int. & n.s. & $-E M$ & $+\mathrm{EM}$ & $-E M$ & + EM & n.s. & n.s. & $-E M$ & $+\mathrm{EM}$ & $+\mathrm{EM}$ \\
\hline \multicolumn{11}{|c|}{ Reed } \\
\hline$p$ & 0.2068 & 0.0002 & 0.0002 & 0.0811 & $<0.0001$ & $<0.0001$ & 0.0536 & 0.0014 & 0.0112 & $<0.0001$ \\
\hline Stat. & 69 & 231 & 0 & 62 & 229 & 2 & 175 & 213.5 & 23 & 5 \\
\hline Int & -EM & $-E M$ & $+\mathrm{EM}$ & n.s. & -EM & $+\mathrm{EM}$ & n.s. & -EM & $+\mathrm{EM}$ & $+\mathrm{EM}$ \\
\hline \multicolumn{11}{|c|}{ Vermicompost } \\
\hline$p$ & 0.0065 & 0.1333 & 0.1149 & 0.0102 & 0.0086 & 0.1621 & 0.0194 & 0.0065 & 0.0084 & 0.0065 \\
\hline Stat. & 78 & 52 & 13 & 1 & 2 & 19 & 72 & 78 & 66 & 78 \\
\hline Int. & -EM & n.s. & n.s. & + EM & +EM & n.s. & -EM & -EM & -EM & -EM \\
\hline
\end{tabular}

Explanation of abbreviations used in Table 1 containing Wilcoxon test results:

$\mathrm{P}$ - test value with Benjamini-Hochberg correction (for multiple testing)

Stat. - testing statistics

Int. - interpretation:

n.s. - not significant - EM - significantly smaller measurement for sewage sludge with EM

$+\mathrm{EM}-$ significantly bigger measurement for sewage sludge with EM

( $\mathrm{p}$ - test value with multiple testing corrections) was the basis for rejecting the zero hypothesis. An alternative test hypothesis was assumed that "significant correlation occurs between the matched pairs". The zero hypothesis is rejected in favor of the alternative hypothesis when $p<0.05$. The results are interpreted in the following way:

- if $S \approx+1$ and $p<0.05$ - parameter values behave consistently and coherently (both increase or decrease); the EM addition does not cause content disorder during the treatment process; both in the sewage sludge with and without EM parameters behave consistently.

- if $S \approx-1$ and $p<0.05$ - parameter values behave coherently but not consistently (one increases while the other decreases). The EM addition causes significant content disorder during the treatment process due to the fact that if the parameter value increases in the sewage sludge without EM, it decreases in the sewage sludge with EM (and vice versa).

- $p>0.05$ - parameter's values behave inconsistently and incoherently (the behavior of one parameter cannot be predicted in the context of another one's behavior). It cannot be statistically predicted how a chosen parameter will behave and what value it will have in the sewage sludge with EM during the treatment process in reference to this parameter in the sewage sludge without EM, which can be interpreted as disorder.
Having analyzed the achieved results of Spearman correlation coefficient significance test for the chosen characteristics and the macroelements content in the dairy sewage sludge treated in the research installations, it can be stated that there is a significant positive correlation $(\mathrm{S} \approx+1$ and $p<0.05$ ) for the vast majority of the examined parameters. The EM addition does not cause any disorder in the content of these parameters during the treatment process; both in the sewage sludge with and without EM, the parameters behave consistently. Only in reference to the content of sulfur in the sewage sludge processed in beds with energy-crop willow and common reed (high content in test with correction $\mathrm{p}$ from 0.1136 to 0.5641 ) it can be stated that the correlation does not exist so the content of this microelement in the sewage sludge with EM during its processing with these methods is incoherent with its content in the sewage sludge containing EM.

Many literature sources, both foreign and domestic, document the influence of EM on the functioning of municipal wastewater treatment plants and the amount and quality of generated sewage sludge. Among other studies, the research conducted by Nathan Szymański and Robert A. Patterson in a municipal wastewater treatment plant in Harbour and in five household wastewater treatment plants (cesspits) in the area of Armidale, Australia. They confirmed that if proper conditions are ensured for EM in tanks, it can be 
Table 2. Spearman test results for chosen characteristics and macroelements content in the dairy sewage sludge treated in the research installations

\begin{tabular}{|c|c|c|c|c|c|c|c|c|c|c|}
\hline & Reaction & $\begin{array}{c}\text { Mineral } \\
\text { substances }\end{array}$ & $\begin{array}{c}\text { Organic } \\
\text { substances }\end{array}$ & $\begin{array}{c}\text { Dry } \\
\text { mass }\end{array}$ & $\begin{array}{c}\text { Total } \\
\text { phosphorous }\end{array}$ & $\begin{array}{c}\text { Total } \\
\text { nitrogen }\end{array}$ & $\begin{array}{c}\text { Total } \\
\text { potassium }\end{array}$ & $\begin{array}{c}\text { Total } \\
\text { calcium }\end{array}$ & $\begin{array}{c}\text { Total } \\
\text { magnesium }\end{array}$ & $\begin{array}{l}\text { Total } \\
\text { sulfur }\end{array}$ \\
\hline \multicolumn{11}{|c|}{ Willow } \\
\hline$S$ & 0.718 & 0.978 & 0.978 & 0.987 & 0.638 & 0.982 & 0.963 & 0.952 & 0.591 & -0.264 \\
\hline$p$ & 0.0007 & $<0.0001$ & $<0.0001$ & $<0.0001$ & 0.0039 & $<0.0001$ & $<0.0001$ & $<0.0001$ & 0.008 & 0.2853 \\
\hline Int. & + & + & + & + & + & + & + & + & + & - \\
\hline \multicolumn{11}{|c|}{ Reed } \\
\hline $\mathrm{s}$ & 0.653 & 0.984 & 0.984 & 0.984 & 0.830 & 0.954 & 0.806 & 0.931 & 0.831 & 0.146 \\
\hline$p$ & 0.0034 & $<0.0001$ & $<0.0001$ & $<0.0001$ & $<0.0001$ & $<0.0001$ & $<0.0001$ & $<0.0001$ & $<0.0001$ & 0.5641 \\
\hline Int. & + & + & + & + & + & + & + & + & + & - \\
\hline \multicolumn{11}{|c|}{ Vermicompost } \\
\hline $\mathrm{s}$ & 0.978 & 0.978 & 0.978 & 0.982 & 0.706 & 0.925 & 0.928 & 0.526 & -0.161 & 0.975 \\
\hline $\mathrm{p}$ & $<0.0001$ & $<0.0001$ & $<0.0001$ & $<0.0001$ & 0.0073 & $<0.0001$ & $<0.0001$ & 0.0631 & 0.614 & $<0.0001$ \\
\hline Int. & + & + & + & + & + & + & + & - & - & + \\
\hline
\end{tabular}

Explanation of abbreviations used in the Table containing the Spearman test results:

$\mathrm{P}$ - test value with Benjamini-Hochberg correction (for multiple testing)

$\mathrm{S}$ - Spearman rank correlation coefficient $(+-$ both parameters compared in pairs increase, - - both parameters compared in pairs decrease)

Int. - interpretation:

+- significant correlation

- - insignificant correlation

observed that the content of solid particles (suspension) decreased and the odor became less intensive [Szymański and Patterson 2003]. Similar results were obtained by Jóźwiakowski in the case of the sewage sludge in household sedimentation tanks (2008). The research was conducted at The University of Science and Technology Qingdao in China concerning the application of EM for treatment of food industry wastewater with a high content of starch and wastewater containing acrylonitrile. In this case, EM was applied with high effectiveness in the contact aeration column [Zhou et al. 2010]. Meanwhile, studies were conducted at South China University of Technology on the damage done to Effective Microorganism's DNA by heavy metals and its influence on the effectiveness of wastewater treatment [Zhou et al. 2008]. At Hohai University in China, research was conducted on the effectiveness of dairy wastewater treatment with the application of various doses of EM. In New Zealand, EM is produced from local microorganisms by Nature Farming Society. It was proven that adding EM can lower the content of COD and the amount of absorbed phosphorous, enhances the sewage sludge sedimentation effect, reduces the odor intensity and moreover it decreases the amount of E.coli and salmonella in wastewater [Liao et al. 2008].

Further studies conducted at The University of Guelph in Canada on the influence of the EM on dairy wastewater quality concerned duckweed. The research carried out in ponds showed that using both EM and duckweed significantly decrease the amount of ammonia nitrogen, total phosphorous, $\mathrm{BOD}_{5}$ and the number of solid particles [Rashid and West 2007]. Applying EM also influences microbiological compositions of the environment, which are water, wastewater, sewage sludge, compost and soil. It was confirmed by multiple studies conducted within the country and abroad. The studies conducted at the Institute of Soil Science and Plant Cultivation in Pulawy on the application of EM in ecological agriculture showed a higher number of microbes and fungi in the soil surface layer [Kowalska 2011]. The research carried out at Inha University in South Korea showed that adding EM to organic waste under composting process has a major effect on increasing the compost maturity, faster odor reduction and mature compost stabilization as well as it allows achieving a higher degree of nitrogen bonding in the soil [Heo et al. 2008]. Similar results proving a positive effect of EM on the speed of composting process and quality of obtained compost were shown by [Boruszko 2016, Sivasubramanian and Namasivayan 2013, Mistra et al. 2003].

However, not all studies unanimously confirm EM's positive impact on soil and cultivation. Among the literature data on the subject of EM's 
influence on the composting process there are such which do not show a positive effect. Among others, Czekała (2013) and Dach et al. (2006) did not confirm any positive influence of applying EM on the total nitrogen cumulated in compost or on the quality of the compost obtained from sewage sludge. Multiple scientific and research studies of many authors undermine the positive impact of EM in environmental elements [Jakubus 2013]. The research conducted in the years 2003-2006 in Zurich, Switzerland, in which EM-A and Bokashi substrate were used to supply soil during farming, showed minor influence on the crops size and soil quality [Mayera et al. 2010]. No positive impact of applying EM was shown with regard to either seeds quality or crops size of pea, corn, rye or potatoes in the studies by, among others, [Mayera et al. 2010 and Priyadi et al. 2005]. In the research conducted by Bielińska et al. (2009) EM showed no significant influence on the formation of nitrogen in soil environment. According to many authors, the disparities in the obtained effectiveness of EM application stem from the competitiveness of domestic bacterial flora present in wastewater, sewage sludge, compost and soil [Pare et al. 1999, Budzińska et al. 2009]. It is also highlighted that EM mixture functions best in such environments where the natural microbiological flora was upset [Janas 2009, Al.-Taweil et al. 2009].

The authors' own research confirmed that due to EM influence, significant changes may occur in the macroelements content in the dairy sewage sludge treated with biological methods. The most significant effect (in reference to the number of parameters and the scale of change influenced by the EM formula) was observed in earthworm vermicomposting process and long-term stabilization in reed beds. The statistical methods applied for evaluating the results of own research (Wilcoxon and Spearman tests) point to a significant influence of the EM formula on different "behaviors" of many analyzed characteristics of the treated sewage sludge. The variety of changes in the treated sewage sludge characteristics was caused by the fact that the microorganisms contained in the EM formula enter very distinct heterogeneous types of environment with domestic bacterial flora. The microorganisms present in the EM formula can thus, under various conditions or harmoniously, cooperate with the domestic microflora, or limit the development of one type of microorganisms by others, which in consequence influence the final content of various components in sewage sludge in various ways. Diversified effect of EM on sewage sludge characteristics in different biological treatment processes were connected with synergistic or antagonistic reactions among particular microorganism species.

\section{CONCLUSIONS}

The conducted research was complex and the obtained results point to the necessity of continuation with regard to the changes of components present in the dairy sewage sludge during its stabilization with natural methods. Determining the role of microorganisms present in the EM formula on each process and change occurring in the sewage sludge stabilized under natural conditions seem to be of particular importance. The innovative characteristic of the research lies in a comprehensive spectrum of the applied natural stabilization methods for treating sewage sludge from dairy wastewater treatment plants. The obtained research results are of utilitarian value as they may be implemented in dairy wastewater treatment plants as innovative solutions which increase the effectiveness of vermicomposting and sewage sludge stabilization in reed beds, among others.

1. Applying the EM formula in sewage sludge stabilization led to significant changes in the macroelements content in biologically treated dairy sewage sludge. The greatest influence was observed for vermicomposting and reed bed stabilization.

2. Organic matter developed during stabilization. The greatest decrease of organic matter was recorded in the sewage sludge stabilized in reed beds.

3. Sewage sludge stabilization conducted under natural conditions caused a drop in the content of all macroelements (except for sulfur). The greatest decrease was observed in nitrogen and the slightest in phosphorous. Adding EM caused an increase of sulfur and magnesium content and a decrease of the calcium content in constructed wetlands with common reed and energy-crop willow. In vermicompost to which EM was applied, the phosphorous and nitrogen content increased while potassium, calcium, magnesium and sulfur decreased in comparison with the vermicompost without EM. 
4. Stabilized sewage sludge complies with the current Regulation of Minister of Agriculture and Rural Development from 2008 for solid organic fertilizers Minister of Environment from 2005 for environmental use of municipal sewage sludge, in reference to heavy metals, which potentially qualifies the dairy sewage sludge as an organic fertilizer.

\section{Acknowledgments}

The study was conducted as a research project S/WBiIŚ/3/2014 in Faculty of Civil and Environmental Engineering at BUT and was financed by Ministry of Science and Higher Education.

\section{REFERENCES}

1. Al.-Taweil H.I., Bin Osman M., Hamid A.A., Yusoff W.M. 2009. Development of microbial inoculants and the impact of soil application on rice seedlings growth, American Journal of Agricultural and Biological Science, 4, 79-82.

2. Anielak A.M. 2008. Gospodarka wodnościekowa przemysłu mleczarskiego, Agro Przemysł, 2, 57-59.

3. Bielińska E.J., Baran S., Stankowski S. 2009. Ocena przydatności popiołów fluidalnych z węgla kamiennego do celów rolniczych, Inżynieria Rolnicza, 6 (115), 7-15.

4. Boruszko D. 2011. Badania i ocena wartości nawozowej kompostów i wermikompostów, Rocznik Ochrony Środowiska, 13 (2), 1417-1428.

5. Boruszko D., Butarewicz A. 2015. Impact of effective microorganisms bacteria on low-input sewage sludge treatment, Environment Protection Engineering, 41 (4), 83-96.

6. Boruszko D. 2016. Determining the effectiveness in vermicomposting of sewage sludges and the attempt to increase the effectiveness by applying bacterial microorganisms, Journal of Ecological Engineering, 17 (3), 53-59.

7. Boruszko D. 2017. Research on the influence of anaerobic stabilization of various dairy sewage sludge on biodegradation of polycyclic aromatic hydrocarbons PAHs with the use of Effective Microorganisms, Environmental Research, 155, 344-352.

8. Budzińska K., Jurek A., Michalska M., Berlec K., Szejniuk B. 2009. Dynamika zmian mikroflory bakteryjnej w składowanych osadach ściekowych, Srodkowo-Pomorskie Towarzystwo Naukowe Ochrony Środowiska, Rocznik Ochrony Środowiska, 4, 1155-1164.
9. Czekała J. 2013. Dynamika przemian związków węgla i azotu w procesie kompostowania kory sosnowej, Journal of Resarch and application in Agricultural Engineering, 58 (3), 81-85.

10. Dąbrowski W., 2006. Management and utylization of sewage sludge from dairy industry wastewater treatment plants, IWA Specialized Conference: state of the art., challengers and pespektives, Moscov, 734-737.

11. Dąbrowski W., 2008. Studies upon heavy metals contens in sewage sludge and reject water produced from its treatment in dairy wastewater treatment plants, ecological chemistry and Engineering, 15 (10), 1041-1047.

12. Dach J., Wolna-Maruwka A., ZbytekZ. 2009. Wpływ dodatku Efektywnych Mikroorganizmów (EM) na przebieg procesu kompostowania i wielkość emisji gazowych, Journal of Resarch and application in Agricultural Engineering, 54 (3), 49-55.

13. Dusza E., Zabłocki Z., NierszczykowskaWójcikowska B. 2009. Content of magnesium and other fertilizer compounds in stabilized sludge from the municipal sewage treatment plant, J. Elementology, 14 (1) 63-70.

14. Heo S.-U., Moon S.-Y., Yoon Ki-S., Kim Y.-J., Koo Y.-M. 2008. Enhanced compost maturity by effective microorganisms, Abstracts / Journal of Biotechnology, 136S, S22-S71.

15. Higa T. 1994. Effective Microorganisms: A New Dimension for Nature Farming. In: Parr J.F, Hornick S.B., Simpson M.E. (Ed.) Proceeding of the second International Conference on Kyusei Nature Farming U.S. Department of Agriculture, 20-22.

16. Higa T. 1996. New Revolution Saving Earth, Sunmark Publishing.

17. IPPC Reference Document on Best Available Techniques In the Food, Drink and Milk Industries, (2006) European Comission.

18. Jakubus M., Gajewski P., Kaczmarek Z., Owczarzak W., Mocek A. 2013. Wpływ dodatków organicznych oraz preparatu EM-A na właściwości chemiczne oraz stan struktury poziomu ornopróchniczego. Część II. Właściwości chemiczne, Journal of Research and Applications in Agricultural Engineering, 58 (3), 220-225.

19. Janas R. 2009. Możliwości wykorzystania efektywnych mikroorganizmów w ekologicznych systemach produkcji roślin uprawnych, Problemy Inżynierii Rolniczej, 3, 111-119.

20. Jóźwiakowski K. „Ocena możliwości stosowania preparatu EM-Farming do optymalizacji pracy osadników wstępnych" Polska Akademia Nauk, $\mathrm{Nr} 5 / 2008$.

21. Kowalska J. 2011. Efektywne Mikroorganizmy w rolnictwie ekologicznym - sprawozdanie, Instytut Ochrony Roślin - Państwowy 
Instytut Badawczy w Poznaniu,. http://www.ior. poznan.pl/plik, 1158,sprawozdanie-zamieszczono-24-11-2011.pdf

22. Liao L., Shao X., Xu J.Z., Walter M. 2008. Effects of Different EM Solution Addition Ratios and Incubation Methods on dairy effluents treatment, Bioinformatics and Biomedical Engineering (iCBBE).

23. Lopez M., Moiron C., Carral E. 2000. Use of dairy sludge as a fertiliser for grass-lands in nortwest Spain: heavy metals levels in the soil and plants, resources, Conservation and Recycling, 30, 95-109.

24. Mayer J., Scheid S., Widmer F., Fließbachb A., Oberholzera H.R. 2010. How effective are 'Effective microorganisms (EM)'? Results from a field study In temperate climate, Elsevier, Applied Soil Ecology, 46, 230-239.

25. Mistra R.V., Roy R.N., Hiraoka H. 2003. On-farm composting methods, Food and Agriculture Organisation of the United Nation, Rome, Italy.

26. Pare T.,DinelH., SchnitzerM. 1999. Extractability of trace metals during co-composting of biosolids and municipal solid wastes, Biol. Fertil. Soils, 29, 31-37.

27. Priyadi K., hadi A., Siagian T.H., Nisa C., Azizah A., Raihani N., Inubushi K. 2005. Effect of soil applications of chicken manure and effective microorganisms on corn yield and microbal properties of acidic wetland soils in Indonesia, Soil Science and Plant Nutrition, 51 (5), 689-691.
28. Rashid M.T. and West J. 2007. Dairy wastewater treatment with Effective Microorganisms and duckweed for pollutants and pathogen control, Wastewater Reuse-Risk Assessment, Decision-Making and Environmental Security Editors:Mohammed K. Zaidi, 93-102.

29. Rosik-Dulewska Cz., Karwaczyńska U., Cieesielczuk T., Gowała K., 2009. Możliwości nieprzemysłowego wykorzystania odpadów zuwzględnieniem zasad obowiązujących w ochronie środowiska, Środkowo-Pomorskie Towarzystwo Naukowe, „Ochrona Środowiska” 11, 863-874.

30. Sivasubramanian S., Karthick Raja Nama sivayam S. 2013. Evaluation of phenol degradation by effective microorganism (EM) technology with EM-1, African Journal of Microbiology research, 7 (32), 4117-4122.

31. Szymanski N. and Patterson R.A. 2003. Effective Microorganisms (EM) and Wastewater Systems,. Lanfax Laboratories Armidale. ISBN 0-9579438-1- 4, 347-354.

32. Zhou Sheng, WEI Chaohai1, LIAO Chaodeng, WU Haizhen, 2008. Damage to DNA of effective microorganisms by heavy metals: Impact on wastewater treatment, Journal of Environmental Sciences 20, 1514-1518.

33. Zhou Guizhong, Li Jia, Fan Huiju, Sun Jing, Zhao Xiaoqing, 2010 .Starch Wastewater Treatment with Effective Microorganisms Bacteria, Bioinformatics and Biomedical Engineering (iCBBE), 1-4. 